\title{
Congratulating Shirley Friedlander Weiss
}

Dr. Shirley F. Weiss was a founding member of SRSA and continues to be one of its most active members. She participates in executive council meetings, regularly attends SRSA conferences, and offers counsel on SRSA affairs. She has served as president of the Association (1977-78) and as vice president and program chair (1976-77). She retired from the faculty at the DCRP, UNC-CH, June 1991, after 33 years of service. The editors agreed that some space in this issue of the Review should be devoted to recognizing her contributions to SRSA to date.

Shirley was quite engaged by regional science when first exposed to the subject in 1956 while studying urban land use planning with Stu Chapin, Jr. (Honorary Fellow of SRSA, 1989). She had a deeper understanding and appreciation for regional science than most of her peers because she was trained as an economist at Rutgers University and at The Johns Hopkins University and had directed economic research at the Maryland State Planning Commission. After receiving her MRP in 1958 at $\mathrm{UNC}$, she remained at UNC, teaching and doing research.

In 1962, Stu Chapin invited Walter Isard to visit UNC to lecture on regional science. Discussions led to the formation of the southeastern section of the RSA, from which SRSA emerged. Shirley was an enthusiastic member from the outset. She has been an effective recruiter of new members to the Association over the years.

Shirley began applying her knowledge of regional science in a major study of cities in the Piedmont Crescent that was funded by the Ford Foundation. That research led to the publication of Growth Dynamics, which she co-edited with Stu Chapin and co-authored the core chapter on land development.

Armed with models of urban development and spatial behavior, Shirley directed a series of research projects that led to the establishment of the Center for Urban and Regional Studies at UNC. Until retirement, she served as associate research director. Her research at the center was supported by grants from the National Science Foundation, several federal agencies (Commerce, Interior, HEW), and private corporations. She lists over 50 publications on her resume.

Shirley formed successful teams of research associates and research assistants and shared credit for the many research accomplishments. She also advised numerous master's theses and doctoral dissertations. Professors Ed Kaiser, Ray Burby, Ben Fisher, Andre Rogers, and Dave Godschalk, among others, pursued their research interests on CURS projects. Concurrently, she completed her Ph.D. in economics at Duke University under the late Joseph J. Spengler. Her dissertation was titled "New Town Development in the United States: Experiment in Private Entrepreneurship." 
Later in her career, she devoted more energy to teaching courses in urban development. Her specialties were central city revitalization, new communities, and entrepreneurship in urban development. She has mentored graduate and undergraduate students at UNC as well as at Duke and NCSU. She communicates with many of them frequently, and they continue to request her advice and assistance.

Shirley participates in a wide range of professional, academic, and community organizations. She is one of four senior fellows of ULI-The Urban Land Institute. She has been elected to offices in RSA, AREUEA, SEAIP, and American Association of University Professors. She has been very active on the UNC-CH campus, having served as chair of the Chancellor's Advisory Committee and faculty marshal from 1988 to 1991. She serves on advisory committees and boards of trustees of performing arts organizations including the Santa Fe Chamber Music Festival, Triangle Opera Theater, and Duke Artist Series. She is on the Board of Trustees of the Friends of the Library-UNC-CH. She travels extensively with her husband, Charles $M$. Weiss, professor emeritus of environmental sciences and engineering, UNC-CH, who has been a long-standing member of RSA and SRSA. Together, they have tracked the progress of urban development projects in more than 50 North American cities as well as European, Latin American, Australian, and Asian cities. They have compiled an incredible collection of slides on the subject. One can find brief summaries of Shirley's career in Who's Who in America and related Who's Who publications.

Shirley says that she is committed to SRSA for many reasons. The Association is multidisciplinary, yet relatively small. It is an open forum for the exchange of ideas. It is well managed. It brings together researchers from government, academia, and the private sector. It generates new activities while sustaining continuity with its past. She has been particularly interested in the educational aspects of SRSA, as well as collegial ones. She sees involving young faculty and new Ph.D.'s as an important mission of the Association. She has enjoyed working with the leaders of SRSA over the years and looks forward to taking on new challenges in the future. 